\title{
Charting African Prosperity Gospel economies
}

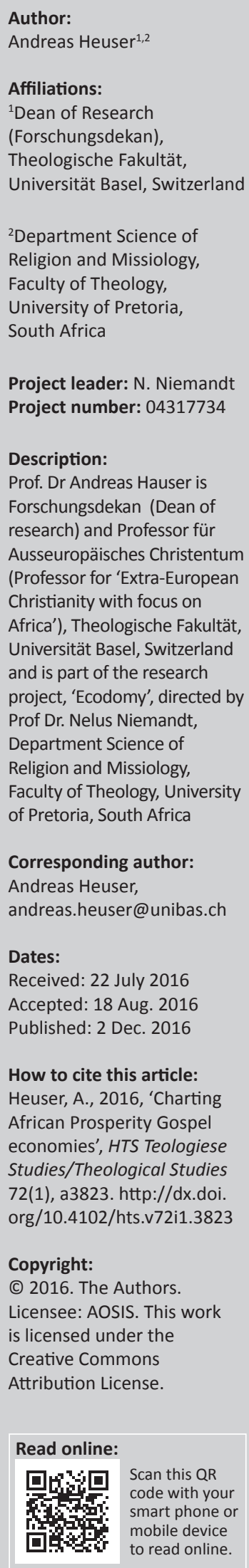

This article maps the vital debate on Prosperity Gospel in Africa and its relevance for socioeconomic change. Prosperity Gospel centres mainly on speech acts surrounding faith, wealth and victory, combined with ritual enactments around secondary evidences of divine blessings. Claiming this-worldly success and material well-being as signs of grace it has captured public spheres and has created African religio-scapes of prosperity. The survey on the socioeconomics of African prosperity-oriented Pentecostalism firstly traces the historic genealogy of Prosperity Gospel as transposable message. It appears as a generic formula in paradigmatic reinventions of Pentecostalism in post-second and/or cold war America and in its globalisation in postcolonial Africa. The double resignification of Pentecostal theology - a rereading of 'mammon' alongside a new ethic of being in the world - relates to the question of socioeconomic agency. Academic discourse connects Prosperity Gospel social capital with interpretations of its ritual texture thriving around rituals of tithings and offerings. Prosperity Gospel economies are profiled as forms of sacral consumption or sacrificial economy, or else as Pentecostal kleptocracy. Contrarily Prosperity Gospel is portrayed as a variant and porter of African social change. The contextualisation of Prosperity Gospel highlights diverse social agency in different milieus. Rural and peri-urban theologies of survival differ from urban progressive and metropolitan business management Prosperity Gospel. The findings defy generalised views on Prosperity Gospel socioeconomics. African Prosperity Gospel indicates a transformative potential in immediate social relationships, whereas claims of impacting structural parameters of society remain, with a few exceptions, part of Pentecostal imagination.

Prosperity is not an 'American gospel'. It will work in Africa, India, China, or anywhere else where God's people practice the truth of His Word. If it is not true in the poorest place on earth, it is not true at all! (Kenneth E. Hagin 2000:200)

\section{Introduction: Mapping African Prosperity Gospel}

African Pentecostal theologising has captured centre-stage in present-day public spaces by a disputed language of desire. Commonly termed as Gospel of Prosperity it has popularised controversial claims of this-worldly success and material well-being as signs of divine grace. A rather undefined concept in systematic theological terms, Prosperity Gospel centres on a complex liaison of speech acts surrounding faith, wealth, health and victory, combined with ritual practices around secondary evidences of divine blessings. An exemplary description comes from the Lausanne Theology Working Group Statement on Prosperity Gospel published in 2010. As a result of a two-year consultation the statement rejects the 'unbiblical notion that spiritual welfare can be measured in terms of material welfare'. Despite such harsh theological critique the Lausanne Theology Working Group (2010) defines Prosperity Gospel as:

The teaching that believers have a right to the blessings of health and wealth and that they can obtain these blessings through positive confessions of faith and the 'sowing of seeds' through the faithful payments of tithes and offerings. (n.p.)

This broad description condenses several theological codes ingrained in Prosperity Gospel. The appeal of such reductionist definition lies in its focus on generic themes which in other words discloses the quality of prosperity theology as a transposable message. The epigraph - a quotation from Kenneth Hagin (1917-2003) who is considered a pioneering figure in what came to known as 'Prosperity Gospel' - reveals the inspirational potency of prosperity promises across geographic and socio-cultural space. It encapsulates the global spread of prosperity theology and hints at local expressions of a specific religious economy. Paraphrasing Thomas Csordas, Prosperity Gospel - 'travels well'. Csordas theorised the modalities of transnational religion and offered two characteristic aspects of successful religious mobility. These he defined as the 'transposability of religious messages', and the 'the portability of religious practises' (Csordas 2009:5). With

Note: This article forms part of the special collection on 'Engaging development: Contributions to a critical theological and religious debate' in HTS Teologiese Studies/Theological Studies Volume 72, Issue 4, 2016. 
Prosperity Gospel we are mapping an ideal-type of a religious complex comprising of the flows of theologies of hope within transnational networks, and the local shaping of prosperity promises and ritual practices.

According to some core statistical findings, an almost canonised notion of Prosperity Gospel has spilled over from Pentecostal milieus to other forms of African Christianity within the last two decades. A 2010 survey on 'Islam and Christianity in Sub-Saharan Africa' highlights a number of statistical trends. The data provided by the renowned Pew Forum on Religion and Public Life (2010:2) show that 'in most countries, more than half of Christians believe in the Prosperity Gospel - that God will grant wealth and good health to people who have enough faith'. Even more remarkably is the transmission of core Prosperity Gospel formulae into the wider relief of African religions. As I defined elsewhere Prosperity Gospel is a resourceful 'theological locus with porous boundaries' into nonChristian terrains (Heuser 2015b:22). Recent observations indicate such trans-religious osmosis of Prosperity Gospel rhetoric, metaphors and practices into African folk-Islam as well as into some layers of traditional African religion. This new cartography of Prosperity Gospel in sub-Saharan Africa highlights the Pentecostalisation of African religious landscapes. Moreover, the emergences of trans-religious beliefs and practices around concepts of material salvation have created what I called 'religio-scapes of Prosperity Gospel' in Africa (Heuser 2015a).

The genealogy of such a transposable message deserves some explanation. But before doing so, it is essential to realise the thoroughly decontextualised semantic offered by the Lausanne Theology Working Group on Prosperity Gospel. Its statement is emptied of any kind of social sensitivity and carries no traces of a political reading of prosperity theology. In contrast to Pentecostal systematic theologian Amos Yong (2012:16) prosperity theology expresses a highly productive 'religious economy', an 'irreducible mix of sociological, economic, political, and historical factors'. It is precisely the relation of Prosperity Gospel to scenarios of social change in Africa which has attracted a significant interdisciplinary attention. Prosperity Gospel has made a steep career in academic discourse. Unparalleled in African postcolonial history a single theological imagery evolved as a potential motivational porter of social transformation.

The debate, however, on the acclaimed Prosperity Gospel variant of African agency remains vital. It is activated by uncertainties over the transformative character of African Pentecostal social capital that traditionally kept distance from worldly affairs. Therefore, in the following article I suggest first a historic reading of generic Prosperity Gospel themes which brings out profound resignifications within Pentecostal theology at large - and these are indeed functional in its societal effects today. Representing a contracted concept of faith, African prosperity theology thrives around ritual enactments of tithings and offerings. The ritual texture of Prosperity Gospel has caused numerous interpretations of the character of Pentecostal social agency. This intense debate is followed up in a subsequent section. However, a generalised statement on Prosperity Gospel as the frame of a Pentecostal ethic of development cannot be supported; it needs to be supplemented in a final paragraph by an effort to contextualise the social praxis of prosperity-oriented churches in diverse empirical milieus.

\section{Genealogy of a transposable message}

The decisive historic point of reference is the post-war or cold war Pentecostal re-invention in America. This crucial phase in Pentecostal history 'has gained comparatively little academic attention so far' (Heuser 2015b:17). In his study of transnational Pentecostal networks, Moritz Fischer identifies the 1950s as the context of intensified efforts to globalise American versions of Pentecostalism. Following his analysis, the American genealogy of Prosperity Gospel is part of an era in which the Pentecostal movement (...) was invented for the second time' (Fischer 2011:240). ${ }^{1}$ The 1940s and 1950s saw the beginning of a movement across denominational lines. Following the historical account by Kate Bowler (2013) diverse theological strands ranging from Pentecostals, Holiness Evangelicalism, American Methodism, AfricanAmerican Baptism or Dutch Reformed Calvinism melded into American Prosperity Gospel. The idea to receive 'blessings through positive confessions of faith' refers to the 'word-of-faith' movement. In the 1940s and 1950s this socalled faith gospel movement coined an explicit religious rhetoric focused on mind power. Exemplified as positive thinking in mainstream Protestantism of the day, and dubbed 'positive confession' in Pentecostal reception it reflected the spoken 'word', the declaration of securing God's blessing. This 'idea of a religious speech act that creates reality (Gn. 1; Jn. 1) empowered a born-again to take directions in life' (Heuser 2015ba:3). Innovative language of 'naming and claiming' divine blessings merged ideas of faith-healing, purity and protection with visions of prosperity for bornagain believers. Pentecostal confidence in faith, thus, signified a double-blessed gospel of health and wealth. Theological terminologies and confessions of faith demonstrated a triumphant mode of belief or - seen more positively - calculate the outcome of a successful life 'making material reality the measure of the success of immaterial faith' (Bowler 2013:7). In this erratic 'health-and-wealth' complex the prosperity aspect merged with the concept of 'seed faith'. The theological construction of 'sowing and reaping' imaged an intimate link between divine blessing and financial contributions to God and the church; it quantifies blessings by preaching that the more you sow the more you will reap. Elaborated rituals of gift exchange with its postures on divine giving and tithing characterised the new style of Pentecostal worship.

In systematic terms Prosperity Gospel deploys a contracted bond of faith, which Kenneth Hagin referred to as the 'law of

1.My translation (A.H.). Allusion is made to the first invention of Pentecostalism at the beginning of the twentieth century, with a global series of revivals from Wales to India, and from America to Korea. 
faith' (Bowler 2013:44-46). As one of the key terms in prosperity theology the 'law of faith' involves a cause-andeffect relationship between a believer and God. If Prosperity Gospel might be rightly defined a 'legal spiritual system' in theological perspective (Bowler 2013:46) ${ }^{2}$, it however stresses the potency of faith, in other words the potentiality, vitality, persistence and pragmatism of Christian hope. In its core, Prosperity Gospel theologises on the interplay between faith and action; it is practical theology, so to speak, with a strong call to enactment. Such faith in action is experimental. Yet, the experimental character of Prosperity Gospel cannot be limited to ritual inventions; its economy of faith action articulates in a quest of re-invention.

Prosperity Gospel indicates a decisive, if not paradigmatic change in Pentecostal theologising. The paradigm consists of two radical breaks in Pentecostal theology: the first is connected to a reframing of being in the world; the second is connected to the discovery of the spiritual value of material substance and wealth. In short, the new 'gospel message' cultivated the classical 'prospects of faith-healing and wellbeing and counted on the self-motivation of a believer to act against all desperate reality' (Heuser 2015b:17) - and by implication to refrain from the retreatist ethics dominant in Pentecostal circles so far. In epic wording Kate Bowler indicates the potential relevance of Prosperity Gospel in American society. She praises its emergence in the post-war period as 'both a siren song and a battle cry' for those at the margins of society (Bowler 2013:54). In the past, Pentecostal theology insisted on the retreat from 'this world', thereby promoting an escapist motive to erect 'counter-societies of the saved-ones immunised against the vicious operations of the devil in society' (Heuser 2013b:57). But now and specifically for African-American Pentecostals 'locked out of the boom years by segregated housing and a discriminatory labour market, divine prosperity promised an end-run around the political, economic, and social forces of oppression' (Bowler 2013:53). The second radical break from classical domains of Pentecostal theology refers to the characteristic material attributes of Prosperity Gospel. Prosperity Gospel undertakes grand efforts to theologise material richness, and to manifest and keep the spiritual control over money. An early indication of the acceptance and the handling of 'dirty', more precisely of demonic, money is the foundation of the Full Gospel Business Men's Fellowship International (FGBMI) in 1952. As an association of Pentecostal-minded businessmen, FGBMI can be considered an ideo-financial centre to delineate prosperity theology. FGBMI forms a strong actor in the global rise of the Pentecostal movement and experiences a virtual explosion in many parts of the African continent since around the 1980s (Kalu 2008:125). The ingenuity of Pentecostal prosperity theology is evident in the most striking resignification of 'mammon' into financial blessing. Otherwise speaking Prosperity Gospel de-spiritualises poverty (Heuser 2013a). In

2.For concise theological critiques of Prosperity Gospel see Werner Kahl (2015) in biblical-hermeneutical perspective, Rudolf von Sinner (2015) in systematic theological perspective and Michael Biehl (2015) in ecumenical perspective. Wilfred Agana (2015) presents a critique of Prosperity Gospel in Ghana from a Roman Agana (2015) prese
Catholic viewpoint. sum, Born-again prosperity theology claims material wealth and breakthroughs of success in life by a double-binding argument: it spiritualises richness and wealth (instead and in opposition to a liberation theology 'option for the poor'), and it purifies money in seed faith and tithing policies. It is, I argue, only by way of ritualising prosperity theology that 'money' becomes a dominant part of Pentecostal imagery and a legitimate aspect in Pentecostal church structures. ${ }^{3}$ This ritual component of a lived Pentecostalism might as well prefigure any constructive vision of social agency.

The genealogy of prosperity theology in American immediate post-war religious history coincided with still another revolutionary concept in Pentecostal self-presentation and social organisation. The basic formulae of what became branded 'Prosperity Gospel' were popularised in the new media of mass communication, such as radio programmes and TV broadcasts. From the 1950s onwards the new modes of communicating the gospel became characteristic features in groupings of individual prosperity preachers. Newly founded independent ministries formed alliances and spread Prosperity Gospel messages through invitation policies in exchange. The inspirational use of mass media climaxed in the setting up of joint conferences and in representative staging of mass-crusades. The establishment of independent, single ministries was backed up by the emergence of how-todo manuals, authored by the new caste of prosperity preachers, and the rise of bible schools and fellowships. These networks enabled the interchange of persons and the flow of ideas in North America. If mobility was already a key to the national spread of Prosperity Gospel imagery, the everexpanding discursive networks helped to de-localise the movement. Prosperity ministries were setting up global network structures. From around the 1960s Prosperity messages were made to travel internationally. Neither confined to the institutional history of a single body of (Pentecostal) churches nor restricted to influences from had a single theological tradition, prosperity preaching had experienced its breakthrough on international scale. The messages of Prosperity Gospel de-localised from its American background and re-localised in contexts of what is now termed the Global South (Fischer 2011:219-41).

Classifying historical passages of prosperity theology in Africa it turned up in the eminent transition into a postcolony. In the first recognisable phase of prosperity preaching from the 1970s to 1990s, single individuals of the stature of Nigerian Benson Idahosa (1938-1998) or Ray McCauly (b. 1949) in South Africa were recognised as representative voices of this new kind of Christian theology. Almost all of them had received their theological a few education in North American Faith Gospel milieus. Within a few years only the African recipients of American prosperity theology evolved as prosperity megastars of their own, visible in the international clusters of Prosperity Gospel conferences. And they mentored numerous African prosperity theologians

3.The theological recoding of material abundance has taken some....................... Pentecostal movement. An example is given with internal shift in perceptions of Pentecostal movement. An example is given with internal shift in perceptions of
financial practice in the Church of Pentecost in Ghana. Nowadays the church perceives financial wealth as generic in ecclesiological terms (Heuser 2013b). 
themselves and in their own theological seminars. With regard to Bowler's sketches of (inter-)national networks of prosperity ministries (Bowler 2013:258-259), the 'grown up' African Prosperity Gospel celebrities were operating independently of American networks from around 2000 onwards. They were forming increasing clusters of international conferences, crusades and autonomous circuits of their own. After half a century Prosperity Gospel had been transposed into a diversity of globalised variants. The subSaharan Prosperity Gospel narrative endorses its transposability. As already mentioned the story unfolds transnational and cross-cultural passages and claims transreligious reception, at least in parts. ${ }^{4}$

\section{Debated 'religious economy'}

The historic review of paradigmatic transformations in Pentecostal theology correlates Prosperity Gospel to experiences of dispossession and disempowerment. However, only tacit indications of Pentecostal social agency are given thus far. If, as stated, Prosperity Gospel has found entry in discourses of diverse fields in African Studies, the answers to the question of how to identify Pentecostal religious economy are multiple. They are framed by theories of globalisation, or by modernisation and development theories, while others provide close-up interpretations of ritual dynamics in single African churches, or locate diverse theologies of prosperity adapted to different socio-cultural milieus.

A considerable strand positions the rise of Prosperity Gospel within global neo-liberal market economies. For Jean and John Comaroff (2004) Prosperity Gospel expresses the largely irrational reaction to the invisible market forces of a globalising economy described as 'millennial capitalism'. The invisible market forces would have manifest effects on everyday life, yet are out of one's personal control which leads to a growing display of what they term 'occult economies' (Comaroff \& Comaroff 2004:35). Such an economy, fuelled by promises of material well-being interpreted as an outward sign of God's favour, celebrates consumption rather than production. To be more precise, the expectation of prosperity praises the immediacy of desire. The instant material gain becomes 'synonymous with the unmediated power of God'. The accumulation of wealth, the Comaroffs conclude, represents an act of 'sacral consumption' (2004:37). Jean Comaroff has recently redirected the vector of analysis from millennial capitalism to post-secular religiocultural traditionalism. By this, in my understanding, she revisits the aspect of Pentecostal 'sacral consumption' as an ideal-type component of a 'politics of affect' in Africa.

4.My understanding of Prosperity Gospel as transposable message tries to avoid recurring deconstructions of Prosperity Gospel as an ideological import to establish a cultural hegemony of American-shaped fundamentalism, as Paul Gifford (1990) has it. The counter-reading employs the same instrumentalist usage of historic genealogy, turned into Africanist positioning. Ogbu Kalu (2008:169) anchors the genealogy, turned into Africanist positioning. Ogbu Kalu (2008:169) anchors the overall explosion of Pentecostalism and by inclusion Prosperity theology in subSaharan Africa unmistakably in an 'African map of the universe'. See also Abraham Kwakye (2015) who traces prosperity theology in African encounters with European missionaries on the Gold Coast. Such a debate on the historical proprietorship of Prosperity Gospel tends to cage a transposable message in Afro-centric gestures of indigeneity and locality $v$ alien impulse in a global project of American cultural and ideological hegemony.
Pentecostalism, she states, shows a 'totalising thrust' to include 'ever more mundane facets of everyday life'; Prosperity Gospel churches 'offer menus of pragmatic services, all day, every day' (Comaroff 2015:227). For Jean Comaroff this is a post-secular Pentecostal return to a traditional African religious makeshift of life, which Pentecostalism otherwise tries to fiercely combat. This pragmatic vision of Prosperity Gospel culture, she claims, 'represents an ironic, late-modern return to the kind of pervasive religiosity, practically integrated with ordinary life, as described in older anthropological accounts of African traditional culture' (Comaroff 2015:227).

Whereas the 'occult economy' analysis portrays the Pentecostal movement as an epi-phenomenon, a reactive answer to dynamics in global capitalism, Simon Coleman (2011) offers a more multidimensional reading of how Prosperity Gospel initiatives 'articulate the connections between "religious" and "economic" spheres of activity' (Coleman 2011:33). Coleman too stresses the Pentecostal agency of ritual action within experiences of marginalisation. Instead of defining hierarchies of dependency or socioeconomic causality he accentuates an explanatory 'model of co-constitution' (Coleman 2011:33). In this vein, Prosperity Gospel should be seen as 'a specific regime of practice, in and through which particular moral and political subjects are produced' (Coleman 2011:33). Whereas the Comaroffs do more or less refrain from examining the peculiar ritual praxis in Prosperity Gospel related Christianity, Coleman insists on ethnographic validity. He seeks to scrutinise the specific Prosperity Gospel orthopraxis, its articulations of faith and its prosperity concepts, and he looks at how these are theologised by Pentecostal believers. He then singles out the performative character of prosperity-oriented churches revolving around a 'sacrificial economy' of offerings and tithings. ${ }^{5}$

The productive factor of Prosperity Gospel may not be reduced to acts of sacrificing. However, Coleman's categorisation helps to address the critical issues in the debate on Pentecostal prosperity teachings. Some of these critical issues relate to the Pentecostal theology of tithing. Prosperity preaching identifies tithing as a central dimension in Christian faith, and rituals of tithing occupy large and at times spectacular sections of services. One could claim that such investment in 'tithing' binds much of innovative energy in prosperity-oriented churches. In the specific connection with 'seed-faith' activity, tithing is a form of sacrificial giving. But how to cope with frustrations over delayed gratification? In the argument of the 'law of faith' the 'sowing' demands a multiplied 'reaping' or return in material benefits. The 'sacrificial economy' therefore is not confined to one-way acts of giving; its ritual composition contains a complementary logic to make plausible the absence of immediate blessings in all day life experiences of a faithful believer. Yvan Droz and Yonatan Gez (2015) convincingly apply Marcel Mauss' theory of gift exchange in this connection. Mauss identified gift 5.Coleman relates to Susan Friend Harding's study (2000:105-23) on the 'sacrificial economics' of American televangelist Jerry Falwell. 
exchange as a category to balance unequal social relations by reciprocal bindings of giver and receiver of gifts. Droz and Gez perceive gift exchange in the form of 'tithing' in Prosperity Gospel milieus as a ritualised binding of both believer and God. It helps explaining the loyalty of believers to Prosperity Gospel promises even when experiencing loss and failure instead of material wealth. In short: the rationale of Pentecostal 'sacrificial economy' addresses a believer's troubled expectation of material signs of divine blessing overwhelmed by a sense of continued marginality.

One could argue that such analysis of Pentecostal 'sacrificial economy' is limited to the management of internal processes, both within a believer and within a church. But it may engage with the wider society. An example for the 'co-constitutional' drive of prosperity theology is set with experiences in diasporic contexts. Jeanne Rey (2015) exemplifies the adaptations in prosperity teachings in Pentecostal African migrant milieus in Europe and North America. Here, the Pentecostal metaphors of 'seed-planting' and 'harvest', materialised in financial blessings and secure status, contrast with constant constraints by immigration realpolitik. In such precarious circumstances the existential plausibility of a 'sacrificial economy' once again comes under severe pressure. Despite the absence of material outward signs of divine grace the attraction of Prosperity Gospel stays intact due to a larger, moral economy of blessings. Within migrant milieus, subjective behavioural repositories of the self, attitudes and norms of faith such as trust, prayer or patience gain prominence and coexist with equal right alongside the lasting hopes in material blessings.

African Pentecostal 'sacrificial economy' discloses its social productivity in the shaping of pastoral careers. Karen Lauterbach (2016) examines the access to hierarchies in smallto medium-sized urban Pentecostal churches in Ghana. She ascribes the making of young, (mostly) male Pentecostal pastors to material investment in social relations. The aspiring Pentecostal pastors accept relations of apprenticeship and dependency for their clear ambition to ascend the ladder of religious and social status. They allocate capital in order to accumulate charismatic power, status and social mobility. The substantial personal sacrifice of money marks the beginning of pastoral careers. These religious entrepreneurs invest in a wide range of activities, from investment in their own higher education to self-organised church-planting events or the setting up of own media activities. All these sacrificial material engagements are part of a strategy to secure spiritual legitimacy and a loyal church membership. Moreover, they are deemed indispensable for ascending church and social hierarchies simultaneously. Religious entrepreneurship and social mobility both draw on local categories of public recognition. Lauterbach (2016), concludes that:

What is remarkable ... is that young men and women are able to 'become someone' in society, achieve status and accumulate wealth through the making of pastoral careers in a general context where the possibilities for social rise are constrained. (p. 19)
Lauterbach frames the Pentecostal access to ministry as a motivational form of religio-cultural entrepreneurship in Africa. A much more sceptical intervention on the use and management of Prosperity Gospel social capital comes from Nigerian sociologist, Asonzeh Ukah. In his compact research oeuvre on Nigerian megachurches, he recurrently detects a 'sacred secrecy' (Ukah 2005:272) surrounding finances. According to Ukah, Nigerian megachurches have turned into mere business empires led by 'prophets for profit' (Ukah 2013), business-minded religious entrepreneurs. The 'prophets for profit' adopt marketing strategies to mobilise and organise funds; they would act as 'economic missionaries' with a prime interest in generating rent instead of supporting spiritual aims (Ukah 2013:151). Church hierarchies are dominated by founding leaders or their representatives. In organisational terms they lack accountability and financial transparency. Relating to incidences of fraud, Ukah deplores the opaque handling of finances and dubious fiscal accountability. He even locates the systemic structure of such a financial 'sacred secrecy' in the global appearance of Nigerian megachurches. As church organisation is highly centralised, it leaves no space for local agency. Therefore, 'locals do not have access to or influence over, how the church finances are managed and expended' (Ukah 2013:151). The 'monetary turn' of Nigerian Pentecostal churches results in the thorough commoditisation of church life. In the final analysis Asonzeh Ukah (2013:145) identifies an instrumental usage of prosperity theology by founders of megachurches in order to 'transform them into economic, financial and entrepreneurial empires which are completely controlled by their families'. What he basically describes is a Pentecostal kleptocracy.

Ukah's verdict on Nigerian megachurches falls short of explaining why, then, such churches excel as megaministries, and what obviously would attract so many believers, even on global levels. This question relates to Ilana van Wyk's (2011) research on the urban based Universal Church of the Kingdom of God (UCKG). Edir Macedo founded Igreja Universal do Reino de Deus 1977 in Brazil. It soon had an enormous attraction in lusophone Africa and since its arrival in 1993 South Africa developed into the most successful region of expansion outside Brazil (Freston 2005). Van Wyk considers UCKG an anomaly within African Christianity as it negates any social dimension of Christian faith. The megachurch offers an ultimate form of Prosperity Gospel, which reduces prosperity theology to a limited set of spiritual techniques and some canonised theological formulae of meeting individual desires. The church encourages its members to 'engage in once-off contracts with God through large monetary funds' (Van Wyk 2011:189). UCKG theology cultivates a utilitarian attitude to faith, strongly discouraging community and socialising aspects in its ecclesiology. The social cohesion of congregations rests on purely individual contracts with God mediated through mass monetary sacrifices, as it were, in church services. The dominant action of members is exactly this sacrificial willingness to give money in the church. 'After sacrificing, members are 
encouraged to demand their blessings from God and not to waste words on praising and worshipping' (Van Wyk 2011:191, emphasis i.o.). Van Wyk summarises UCKG Prosperity Gospel consequently as a way of 'believing practically and trusting socially', however in a social anomaly of a mass of monadic individuals. Being a member in this church means to activate individual financial offerings in order to keep one's personal desires alive, and to concentrate such action in a joint service of 'strangers' who remain strangers to each other (Van Wyk 2016). The church does even negate acts of community building and charity. All empathic motives of a believer to address existential needs and desires of fellow-believers, or more so of outsiders are branded as strategic satanic weapons in subverting God's kingdom. The antagonistic perception of social outreach programmes negates offerings to poorer church members and strictly denies addressing poverty within society.

This is the central perception of prosperity theology offered by Paul Gifford. Since his pioneering reading of Pentecostal prosperity teachings around 1990, Gifford underlines their limited take on societal and structural matters. Prosperity doctrine would subvert any effort 'to promote self-help, self-reliance, self-esteem, self-determination, responsibility, and autonomy' (Gifford 1991:10). In his recent outline of the Pentecostal movement's general role in the socioeconomic transformation of African societies Gifford (2015a:47-68) still remains sceptical. He scrutinises the theology of Nigerian David Oyedepo. In Gifford's view Oyedopo 'is prepared to take prosperity to its logical conclusion' (Gifford, P., 2013, 16 December, pg@soas.ac. uk). In 1983, Oyedepo founded one of the most prominent new churches on the African continent, Living Faith Church Worldwide, better known as Winners' Chapel. Gifford observed the theological dynamics of Oyedepo's Prosperity Gospel over several decades. In Gifford's long-term analysis, Oyedepo's prosperity theology has kept a perspective strictly limited to individual prospects of success, or internal church-related affairs. In his final analysis of Oyedepo's theology Gifford (2015b:97-98) explicates a purist form of prosperity theology that bears no traces of political theology. Neither would Oyedepo in his writings engage in the wider world nor would he be interested in changing social systems or challenging poverty by alternative economies.

How can one summarise this debate on the characteristics of Prosperity Gospel religious economy? Actual research on African Prosperity Gospel variants seems unanimously raising doubts over their social capacity. In the overall picture, the socioeconomics of Prosperity Gospel-related churches ranges somewhere between energising individual believers and the cohesion of single churches, to outright scepticism over and even denial of any church engagement in society. Prosperity theology sometimes excludes social programmes by definition and dismays long-term goals in social change. In empirical perspective, however, these findings deserve some corrections.

\section{Transformational social agency}

In empirical terms Prosperity Gospel social profiles are not uniform but diversify according to social milieus and contexts. In his study on Nigerian Pentecostalism, Musa Gaiya (2015) categorises this vast spectrum of churches according to their social impact and management of resources. Gaiya offers a dual typology by differentiating centripetal from centrifugal churches. Whereas centripetal Pentecostalism is characterised by an inward-looking ecclesiology, centrifugal churches discover a more outwardlooking praxis, employing resources for 'practical social improvement' (Gaiya 2015:64). This strand of engaged Pentecostalism is comparatively small but exerts some growing impact in Nigerian society. Prosperity Gospel does not explicitly feature as a parameter in Gaiya's cataloguing of Pentecostal churches. It is however remarkable to find strong prosperity-oriented churches in both of his centrifugal and centripetal sections.

Gaiya's empirical base is restricted to metropolitan Lagos. His local data on centrifugal churches match with an emergent type of socially aware Pentecostalism on global scale. In a first global survey of Pentecostal churches Donald Miller and Tetsunao Yamamori have identified an urban based 'progressive' Pentecostalism (Miller \& Yamamori 2007). ${ }^{6}$ By this category they signify middle-class churches that are located in metropolitan, urban and peri-urban areas, emphasising active social ministries. Members are upwardly mobile and rather well educated. They firmly heed to the image of religious entrepreneur and raise enormous funds. According to Miller and Yamamori (2007:2) a number of these progressive Pentecostal churches are 'addressing the social needs of people in their community'.

A quantitative empirical study on South African churches, conducted in 2007, relates such observations to ethical formats. The findings, evaluated by Helga Dickow, are mainly based on churches in Soweto. They evidence a socially constructive, born-again consciousness of prosperityoriented Pentecostal churches. Church leaders as well as members claim social responsibility in the new South Africa. They show a high sensitivity on poverty alleviation. Members 'consider the gap between rich and poor to be far wider than any other difference in South African society including racial, religious and ethnic ones' (Dickow 2012:192).

Even in comparison with other churches the data on attitudes are convincing. In a separate article that analyses specific data from the empirical study (2007) Dickow and Valerie Møller correlate the representative South African sample with a focus group of members of the Sowetan-based Grace Bible Church. Grace Bible Church members explicitly consider education, skills training programmes and hard work as imperative factors to address social misery (Dickow \& Møller 2008). Church representatives and ministers from

6.Miller and Yamamori represent a bird's eye perspective on the global Pentecostal movement. They gained their insights from short-time travels for two months in movement. They gained their insights from short-time travels for two months in
each year to at least three countries. Overall, they visited 20 different countries in Asia, Africa, Latin America and Eastern Europe. 
Grace Bible Church claim to initiate concrete outreach projects. These are mostly neighbourhood and charityoriented outreach projects ranging from food distribution to the poor to literacy programmes, from the care for the elderly to rehabilitation of ex-prisoners, from HIV-related projects to the pastoral care of abused women and children (Mathole 2008). The variety of initiatives in centrifugal, progressive Pentecostalism seems remarkable.

The correlation of Pentecostal prosperity theology with an ethics of social responsibility has triggered a key debate guided by 'modernity' assumptions. The urgency to define a certain set of behavioural codes as markers of Pentecostal socio-economic potential and mobilising social ambition revitalises Weberian concepts of the protestant capitalist ethic. Such positioning is strongly advocated by Peter. L. Berger's 'simple but far-reaching, proposition' made in a public lecture at the University of the Witwatersrand on 'Faith and Development' in March 2008: 'Pentecostalism should be viewed as a positive resource for modern economic development' (Berger 2008:5). The confidence in view of the transformational quality of Pentecostal prosperity theology is great. In her influential contribution on 'the Pentecostal ethic and the spirit of development' in Africa Dena Freeman (2012) stated that the Pentecostal features of individual transformation of believers would efficiently result in an ethic of sustainable development. The background of her research is Ethiopian rural highland Pentecostalism. Pentecostal churches would be 'more successful in bringing about change that is effective, deep-rooted and long-lasting' than historically established (orthodox and western mission derived) Christianity or even secular non-govermental organisations (NGOs) (Freeman 2012:24).

The debate on the connection between Pentecostal techniques of personal transformation and empowerment for social changes is still ongoing (Berger 2010; Drønen 2015; Hayward \& Kemmelmeier 2011). Its course shows that categorical assumptions on Prosperity Gospel churches as legitimate and effective change agents are implausible. Paul Gifford voices a hermeneutics of suspicion over and against Pentecostal assertions of discipline and hard work. He suspects them to belong to a rhetorical set of Pentecostal selfdesigns in globalising African economies (Gifford 2004:154). Supported by empirical South African samples, the ethical authenticity of Prosperity Gospel churches remains dubious. Following some data on South African Pentecostal Christianity presented by the Johannesburg-based Centre for Development and Enterprise the dubious management of financial resources is still disputed and even applies to smaller Pentecostal churches as well. It is precisely this Centre that had invited P.L. Berger for his lecture in March 2008. In view of South African urban and rural smaller Pentecostal churches, the Centre for Development and Enterprise (2012:72) considers the deficiency of organisational control as their greatest challenge: 'Perhaps the greatest concern is that some of the entrepreneurial pastors in smaller community churches are enriching themselves at the cost of devout but naïve followers'. This sheds doubts on whether the implementation of such social outreach projects mentioned above is effective or not.

Generalising statements on Prosperity Gospel churches as modern agents for socioeconomic transformation need to be tested by comparative case-study approaches in different social contexts. In insecure local environments, for instance, the Pentecostal theology of prosperity bears the contours of a more introverted message. For instance, in impoverished townships or slums the social reach of Prosperity Gospel messages is oriented to meet existential needs. In their social praxis Pentecostal churches are almost copying the profile and characteristic features of small African Instituted Churches (AIC) that are much older components of township Christianity than prosperity-oriented churches (Cross et al. 1992:21-27; Anderson \& Otwang 1993:61). Like AIC small Pentecostal churches form neighbourhood support groups that are reactive rather than proactive in nature; they might create small networks of solidarity such as funeral societies or bursary funds for the education of their children, however with little structural impact on society at large. Harri Englund (2011:17) rightly observes that it is the 'quest for security rather than for prosperity' that 'animates the Pentecostal imagination'. In a typology of prosperityoriented Pentecostalism in Africa the Prosperity Gospel in small-scale, peri-urban (and possibly most rural) socioeconomic milieus articulates a 'silent theology of survival' (Heuser 2013a:163-164). This is far from proclaiming an illustrious religious entrepreneurship in middle-class, urban Pentecostalism, or from coining another 'spirit of capitalism' expressed by metropolitan megachurches.

Furthermore, the social capital expressed by urban, progressive Pentecostalism remains ambiguous. Miller and Yamamori (2007:127) qualify the kind of social praxis of progressive Pentecostals as 'heroic intensity'. Such puzzling phrasing leaves an impression of activism rather than longterm effects in handling social projects. Consequently, Pentecostal social ministries might still lack professionalism. Their inward-looking social cohesion may still be stronger than social networking. This assumption, at least, can be drawn out from South African surveys researched by Dickow (2012). According to her empirical data the design of Pentecostal grassroots projects does 'not show a high level of trust in their social environment'; even Pentecostals qualified 'progressive', 'tend to feel closest to their co-religionists' in the church (Dickow 2012:193). The centrifugal evidence of progressive Pentecostal effect on local contexts and social cooperation seems doubtful.

\section{Outlook: Pentecostal business management ecumenism}

So far, measurable proof of African Pentecostal agency to improve social life is small. Some initiatives, however, direct towards strategic implementation of entrepreneurial praxis. They are characterised by long-term networking beyond the range of the same church or church family. Such interaction is 
basically generated between African Progressive Pentecostals and American churches of the evangelical left, that is churches with a stronger socio-political profile. Back in 2001 Paul Freston envisaged such cooperation triggered by an 'increasingly "social" discourse of prosperity teachers' (Freston 2001:315). Their common target is to impact society by practical aspects of prosperity theology. For this reason they engage in business education programmes, either in bilateral cooperation between single churches, or in broader 'ecumenical' initiatives.

A loose enterprise of connecting local churches refers to the so-called PEACE programme initiated by Rick Warren of Saddleback Church in California in 2005. Warren is the author of two bestsellers ('The Purpose Driven Life' and 'The Purpose Driven Church') with which he aims at addressing the five 'Global Goliaths', the problems of 'spiritual emptiness, selfish leadership, poverty, disease and ignorance' (quoted in Gifford 2009:149). East Africa has been selected as a pilot area to conduct a series of, as it were, 'purpose driven' conferences. The conference programme seeks to familiarise African churches with business management Christianity. These seminars are open to any church. The acronym PEACE stands for 'plant a church or partner with an existing one'; 'equip local leaders'; 'assist the poor'; 'care for the sick'; 'educate the next generation'. This programme advocates ideas of modern management studies and marketing strategies to be implemented in Pentecostal church structures. It promotes techniques of administration and investment, norms of accounting, the handling of debts as elementary aspects of church structures. Participants are encouraged to transfer entrepreneurial skills into congregational life and use these skills in the management of social projects run by churches (Heuser 2013b:65-67). If this project intends to connect representatives of diverse churches around the idea of business management, other initiatives are geared towards a viable institutional network of churches.

David Daniels III (2015) exemplifies one such joint venture between African and African-American prosperity-oriented megachurches. The interchanges between American televangelist Bill Winston of Living Word Christian Centre (Chicago) and Nigerian mega-church ministry of Samuel Adeyemi of Daystar Christian Centre (Lagos) support entrepreneurial ambitions by favouring business educational projects. This includes the founding of educational institutions with a priority on economics. Their mission statements stress personal responsibility for acquiring business skills and strategic business behaviour for realising material wealth. In such intentional cooperation between single African-American and West African megaministries, Daniels observes the move from consumption of wealth to entrepreneurship.

According to these recent observations the pragmatic revision of Prosperity Gospel takes place when Prosperity Gospel doctrines merge with business education. This still occupies a smaller section of prosperity theology-oriented African Pentecostalism. In general, the intense scholarly debate on
Prosperity Gospel and the connection between African Pentecostalism and socio-economic change defies a generalised view. Prosperity Gospel concepts relate to a diversity of Pentecostal perspectives on society and disclose a varied agency in socio-economic change. A township-based ethics of survival is different from an urban and middle-class 'progressive' Pentecostalism; while business management oriented churches have aspirations to transform society, the socio-economic horizon of churches entertaining a strong sacred secrecy around prosperity rather remains short-term and confined to internal dynamics. However, the actual impact of Prosperity Gospel messages in the broader landscape of churches is growing. This goes along with a general tendency to explore social outreach programs. At least, as I argued elsewhere, 'poverty alleviation has meanwhile become an integral part of the self-perception of the Pentecostal movement' (Heuser 2013a:167, author's translation). At this stage, the Pentecostal narrative of social awareness in most cases follows the Prosperity Gospel semantics of success, transformation and visibility in society. Despite all heterogeneity some key elements of African Prosperity Gospel substantiate the Pentecostal ambition to impact socio-economic life. Prosperity Gospel-oriented churches are usually self-funded and focus on individual transformation. Pentecostal techniques of the self encouraged 'breaking with the past' (rather than a post-secular revisit of it). This may lead to transformations of immediate social relationships, like opting out of family networks or substituting expensive feasts and rites of passage (funerals, weddings). I join in the argument pushed by David Maxwell (1998) that
a 'complete break with the past' contributes to the creation of free subjects able to embrace certain aspects of modernity. (...) As well as becoming freer to accumulate, the new believer is smart in appearance, trustworthy, hardworking and literate, and hence employable. (p. 354)

Their strong sense of identity formation, at least, has energising effects on a pro-capitalist or entrepreneurial ethos. The Pentecostal spiritual economy of self-discipline cultivates inner-worldly materialism and success orientation. The stress on born-again personal transformation can obviously mobilise social participation. In terms of life attitudes members of Prosperity Gospel churches 'feel less powerless, are less afraid of the future, and are more willing to accept change' (Dickow 2012:193). Yet, the Pentecostal prosperity theology impact on structural parameters of society is still in need of closer empirical investigation - so far, it remains visionary.

\section{Acknowledgements}

I am grateful to the sub-editors for inviting me to contribute to this special collection.

\section{Competing interests}

The author declares that he has no financial or personal relationships which may have inappropriately influenced him in writing this article. 


\section{References}

Agana, W.A., 2015, 'Succeed here and in eternity': The prosperity gospel in Ghana Lang, Frankfurt.

Anderson, A. \& Otwang, S., 1993, Tumelo: The faith of African Pentecostals in South Africa, University of South Africa Press, Pretoria.

Berger, P.L., 2008, Faith and development: A global perspective, Centre for Development and Enterprise Public Lectures, 2008, viewed 20 May 2016, from http://www.cde. org.za/wp-content/uploads/2013/02/Faith_and_Development.pdf

Berger, P.L., 2010, 'Max Weber is alive and well, and living in Guatemala: The Protestant ethic today', The Review of Faith \& International Affairs 8(4), 3-9. http://dx.doi.org/10.1080/15570274.2010.528964

Biehl, M., 2015, 'To prosper and to be blessed: Prosperity, wealth and "life in abundance" in ecumenical debate', in A. Heuser (ed.), Pastures of plenty: Tracing religio-scapes of prosperity gospel in Africa and beyond, pp. 131-145, Lans, Frankfurt.

Bowler, K., 2013, Blessed: A history of the American prosperity gospel, Oxford University Press, Oxford.

Centre for Development and Enterprise, 2012, 'South Africa, under the radar: Pentecostalism in South Africa and its potential social and economic role', in K. Attanasi \& A. Yong (eds.), Pentecostalism and prosperity: The socio-economics of the global charismatic movement, pp. 63-85, Palgrave Macmillan, Basingstoke.

Coleman, S., 2011, 'Prosperity unbound? Debating the "Sacrificial Economy"', in L. Obadia \& D. Wood (eds.), The economics of religion: Anthropological approaches, pp. 23-45, Emerald, Bingley.

Comaroff, J., 2015, 'Pentecostalism, "Post-Secularism", and the politics of affect in Africa and beyond', in M. Lindhardt (ed.), Pentecostalism in Africa: Presence and impact of Pneumatic Christianity in postcolonial societies, pp. 220-247, Brill, Leiden.

Comaroff, J.L. \& Comaroff, J., 2004, 'Privatising the millennium: New protestant ethics and spirits of capitalism in Africa, and elsewhere', in D. Chidester, A. Tayob \& W. Weisse (eds.), Religion, politics, and identity in a changing South Africa, pp. 24-43, Waxmann, Muenster.

Cross, C., Oosthuizen, G.C., Bekker, S. \& Evans, J., 1992, Rise up and walk: Development and the African Independent Churches in Durban, Department of Development Aid, Durban.

Csordas, T.J., 2009, 'Introduction: Modalities of transnational transcendence', in T.J. Csordas (ed.), Transnational transcendence: Essays on religion and globalisation, pp. 1-29, University of California Press, Berkeley, CA.

Daniels, D.D., III, 2015, 'Prosperity gospel of entrepreneurship in Africa and Black America: A pragmatist Christian innovation', in A. Heuser (ed.), Pastures of plenty: Tracing religio-scapes of prosperity gospel in Africa and beyond, pp. 265-277, Lang, Frankfurt.

Dickow, H., 2012, Religion and attitudes towards life in South Africa: Pentecostals, charismatics and reborns, Nomos, Baden-Baden.

Dickow, H. \& Møller, V., 2008, 'Let's face the world! Comparison between members of a new Pentecostal/charismatic church and other Christians in Gauteng', in H. Dickow \& A. Heuser (eds.), Religion on the move: Exploring passages in South African A. Heuser (eds.), Religion on the move: Exploring passages in South African
Christianity, pp. 77-98, UNESCO International Centre for Social Sciences, Byblos.

Drønen, T.S., 2015, “"Now I dress well. Now I work hard" - Pentecostalism, prosperity, and economic development in Cameroon', in A. Heuser (ed.), Pastures of plenty:
Tracing religio-scapes of prosperity gospel in Africa and beyond, pp. 249-263, Tracing religio-scar
Lang, Frankfurt.

Droz, Y. \& Gez, Y.N., 2015, 'A God trap: Seed planting, gift logic, and the prosperity gospel', in A. Heuser (ed.), Pastures of plenty: Tracing religio-scapes of prosperity gospel, in A. Heuser (ed.), Pastures of plenty: Tracing religio-
gospel in Africa and beyond, pp. 295-307, Lang, Frankfurt.

Englund, H., 2011, 'Introduction: Rethinking African Christianities. Beyond the religion-politics conundrum', in $\mathrm{H}$. Englund (ed.), Christianity and public culture in Africa, pp. 1-24, Ohio University Press, Athens, $\mathrm{OH}$

Fischer, M., 2011, Pfingstbewegung zwischen Fragilität und Empowerment Beobachtungen zur Pfingstkirche 'Nzambe Malamu' mit ihren transnationalen Verflechtungen, V\&R unipress, Göttingen.

Freeman, D., 2012, 'The Pentecostal ethic and the spirit of development', in D. Freeman (ed.), Pentecostalism and development: Churches, NGOs and socia change in Africa, pp. 1-38, Palgrave Macmillan, Basingstoke.

Freston, P., 2001, Evangelicals and politics in Asia, Africa and Latin America, Cambridge University Press, Cambridge.

Freston, P., 2005, 'The universal Church of the kingdom of God: A Brazilian Church finds success in South Africa', Journal of Religion in Africa 35(1), 33-65. http:// dx.doi.org/10.1163/1570066052995816

Gaiya, M.A.B., 2015, 'Charismatic and Pentecostal orientations in Nigeria', Nova Religio 18(3), 63-79. http://dx.doi.org/10.1525/nr.2015.18.3.63

Gifford, P., 1990, 'Prosperity: A new and foreign element in African Christianity', Religion 20(4), 373-388. http://dx.doi.org/10.1016/0048-721X(90)90119-Q

Gifford, P., 1991, 'Christian fundamentalism and development in Africa', Review of African Political Economy 19(52), 9-20. http://dx.doi.org/10.1080/0305624910 8703918
Gifford, P., 2004, Ghana's new Christianity: Pentecostalism in a globalising African economy, Indiana University Press, Bloomington, IN.

Gifford, P., 2009, Christianity, politics and public life in Kenya, Hurst, London.

Gifford, P., 2015a, Christianity, development and modernity in Africa, Hurst, London.

Gifford, P., 2015b, 'The prosperity theology of David Oyedepo', in A. Heuser (ed.), Pastures of plenty: Tracing religio-scapes of prosperity gospel in Africa and beyond, pp. 83-100, Lang, Frankfurt.

Hagin, K.E., 2000, The midas touch: A balanced approach to biblical prosperity, Kenneth Hagin Ministries, Tulsa, OK.

Harding, S.F., 2000, The book of Jerry Falwell: Fundamentalist language and politics, Princeton University Press, Princeton, NJ.

Hayward, D.R. \& Kemmelmeier, M., 2011, 'Weber revisited: A cross-national analysis of religiosity, religious culture, and economic attitudes', Journal of Cross-Cultural Psychology 42, 1406-1420. http://dx.doi.org/10.1177/0022022111412527

Heuser, A., 2013a, "'Refuse to Die in Poverty!", Armutsüberwindung und Varianten des Wohlstandsevangeliums in Afrika', Theologische Zeitschrift 69(1-2), 146-171.

Heuser, A., 2013b, 'Trajectories into the world: Concepts of "development" in contemporary African Pentecostal Christianity', in K. Mtata (ed.), Religion: Help or hindrance to development?, pp. 51-68, Evangelische Verlagsanstalt, Leipzig.

Heuser, A. (ed.), 2015a, Pastures of plenty: Tracing religio-scapes of prosperity gospe in Africa and beyond, Lang, Frankfurt.

Heuser, A., 2015b, 'Religio-scapes of prosperity gospel: An introduction', in A. Heuser (ed.), Pastures of plenty: Tracing religio-scapes of prosperity gospel in Africa and beyond, pp. 15-29, Lang, Frankfurt.

Kahl, W., 2015, “Jesus became poor so that we might become rich." A critical review of the use of biblical reference texts among prosperity preachers in Ghana', in A. Heuser (ed.), Pastures of plenty: Tracing religio-scapes of prosperity gospel in Africa and beyond, pp. 101-115, Lang, Frankfurt.

Kalu, O., 2008, African Pentecostalism: An introduction, Oxford University Press, Oxford.

Kwakye, A.N.O., 2015, 'Encountering "prosperity" gospel in nineteenth century Gold Coast: Indigenous perceptions of Western missionary societies', in A. Heuser (ed.), Pastures of plenty: Tracing religio-scapes of prosperity gospel in Africa and beyond, pp. 217-228, Lang, Frankfurt.

Lausanne Theology Working Group, 2010, A statement on the prosperity gospel, viewed 14 May 2016, from https://www.lausanne.org/content/a-statement-onthe-prosperity-gospel

Lauterbach, K. (2016), 'Religious entrepreneurs in Ghana', in U. Röschenthaler \& D. Schulz (eds.), Cultural entrepreneurship in Africa, pp. 19-36, Routledge, New York.

Mathole, E.M.K., 2008, 'Beyond common stereotypes about the Pentecostalcharismatic evangelicals in South Africa', in H. Dickow \& A. Heuser (eds.), Religion on the move: Exploring passages in South African Christianity, pp. 59-75, UNESCO on the move: Exploring passages in South African
International Centre for Social Sciences, Byblos.

Maxwell, D., 1998, “"Delivered from the Spirit of Poverty?”: Pentecostalism, prosperity and modernity in Zimbabwe', Journal of Religion in Africa 28(3), 350-373. http:// dx.doi.org/10.2307/1581574

Miller, D.E. \& Yamamori, T., 2007, Global Pentecostalism. The new face of Christian social engagement, University of California Press, Berkeley, CA.

Pew Forum on Religion and Public Life, 2010, Islam and Christianity in sub-Saharan Africa, PEW Forum on Religion and Public Life, Washington, DC.

Rey, J., 2015, 'Missing prosperity: Economics of blessings in Ghana and the diaspora', in A. Heuser (ed.), Pastures of plenty: Tracing religio-scapes of prosperity gospel in Africa and beyond, pp. 339-353, Lang, Frankfurt.

Ukah, A.F.K., 2005, 'Those who trade with God never lose: The economics of Pentecostal activism in Nigeria', in T. Falola (ed.), Christianity and social change in Africa: Essays in honor of J.D.Y. Peel, pp. 253-274, Carolina Academic Press, Durham, NC.

Ukah, A.F.K., 2013, 'Prophets for profit: Pentecostal authority and fiscal accountability among Nigerian churches in South Africa', in A. Adogame, M. Echtler \& O Freiberger (eds.), Alternative voices: A plurality approach for religious studies, pp. 134-159, Vandenhoek \& Ruprecht, Göttingen.

Van Wyk, I., 2011, 'Believing practically and trusting socially in Africa: The contrary case of the Universal Church of the Kingdom of God in Durban, South Africa', in H. Englund (ed.), Christianity and public culture in Africa, pp. 189-203, Ohio University Press, Athens, $\mathrm{OH}$.

Van Wyk, I., 2016, The Universal Church of the Kingdom of God in South Africa: A Church of strangers, Cambridge University Press, Cambridge, GB.

Von Sinner, R., 2015, "'Struggling with Africa": Theology of prosperity in and from Brazil', in A. Heuser (ed.), Pastures of plenty: Tracing religio-scapes of prosperity gospel in Africa and beyond, pp. 117-130, Lang, Frankfurt.

Yong, A., 2012, 'A typology of prosperity theology: A religious economy of the global renewal or a renewal economics?', in K. Attanasi \& A. Yong (eds.), Pentecostalism and prosperity: The socioeconomics of the global charismatic movement, pp. 15-33, Palgrave Macmillan, New York. 